\title{
A Critical Policy Analysis of Early Childhood Education (ECE) in Indonesia
}

\author{
Desvi Wahyuni ${ }^{1, *}$, Rudiyanto $^{2}$ \\ 1,2 Department Early Childhood Education, School of Postgraduate, Universitas Pendidikan Indonesia, Bandung, \\ Indonesia \\ *Corresponding author. Email: desvi.wahyuni@upi.edu
}

\begin{abstract}
Education is a basic right of citizens that shall be fulfilled by the state. Thus, as the embodiment of the fulfilment of the citizens' rights, the state creates policies that are applicable to all components of the society regarding education. For early childhood education (ECE), in particular, the government has created a more flexible basic policy for early childhood education, thus providing people with the opportunity to participate in its implementation. This is also seen from the government's effort in dividing the institutional forms into Formal and Non-formal ECE, thus the access to service to ECE is better reachable by everyone. Although there have been regulations on ECE in Indonesia, there are several policies that are incongruent with the practices on the field, such as the implementation and the students. Besides, the involvement of other parties in regulating early childhood education causes policies to overlap in its implementation. Based on the aforementioned, this article aims to provide an overview on early childhood education policies in Indonesia. By using literature study method regarding this critical policy analysis of early childhood education in Indonesia, this article is expected to provide a clear description on the reason behind the existence of early childhood education in Indonesia, including the involvement of other factors that support its policy making process.
\end{abstract}

Keywords: Education policy, early childhood education, Indonesia.

\section{INTRODUCTION}

The Dakar Declaration in 2000 regarding Education for All (EFA) has put early childhood education (ECE) into the main priority program for UNESCO member states, including Indonesia. In Indonesia, ECE programs are evident through the appeal of Satu Desa Satu Paud (One Village, One ECE) [1]. This causes the number of ECE institutions to increase each year in Indonesia since 2015-2020 [2]. Besides, the efforts to integrate education, nutrition and health, care, and protection for children through a Holistic Integrative ECE [3] are the proof of the government's seriousness in the fulfilment of children's rights. Furthermore, the Regulation of the Minister of Education and Culture No. 137 of 2014 regarding National Standard for Early Childhood Education displays the government's preparedness to contribute in the fulfilment of the EFA program.

This regulation on ECE has made the people participate in the implementation. Quoted from the official website of Dapodik Paud dan Dikmas (National Data for Early Childhood Education and Public Education), there are currently 2014.150 ECE institutions in 3 administration tracks. These three tracks are contained in Law No. 20 of 2003 regarding the National Education System. These tracks are formal, non-formal, and informal tracks.

Although the existence of ECE in Indonesia is mapped into three different tracks with standards adjusted based on the types of institutions, the three tracks are intended for children aged 0 to 6 years and adapted to the needs of each child [4]. The forms of ECE institutions in Indonesia include Kindergarten (TK) and Raudhatul Atfal (RA) which are included in the formal track; Playgroups, Child Care Centers, and Similar Units which are included in the non-formal track (SPS). As for ECE institutions which are included in the Similar Unit are Bina Iman Anak, Taman Pendidikan Al-Quran, or etc with students in the age range of 0-6 years. In addition, Similar ECE Units, especially those in rural areas, are established by village officials with the same form of services such as kindergarten or play groups [5].

This policy, which divides ECE into three administration tracks and types of institution, causes new problems. There are policy overlaps, especially regarding 
the implementation. The authors assumed that the lack of socialization and the other supporting factors made ECE institutions to be different between one another. Therefore, without realizing it, it has become something attached within the society. In this article, the author is interested to see how the policy on early childhood education is implemented in the society, as well as the other factors that support the creation of such regulation. Further, by using a literature study method on the policy implementation of early childhood education, the author expects to holistically describe the early childhood education forms of services in the society that are in compliance with the policy and technical guidelines regulated by the state.

\section{EARLY CHILDHOOD EDUCATION (ECE) POLICY IN INDONESIA}

Based on Law No. 20 of 2003 on the National Education System, early childhood education or ECE is an educational service intended to children of 0-6 years old in order to prepare them for primary school. This regulation made early childhood education an obligation that must be conducted by everyone. Besides, with the regulation regarding early childhood education, the government stated that they would establish early childhood education in many regions under the government's program named Satu Desa Satu Paud (One Village, One ECE) [6]. This program is intended to equalize the distribution of early childhood education among villages, thus every young child will be able to access education services based on their age [7].

Setting early childhood education as a priority program in education development in Indonesia means to involve every group to participate in its implementation. Therefore, the government provides assistance funds for the fulfilment of supporting facilities such as educational game tools, operational assistance for implementation, and so on as an effort to implement the program [6]. Even though the government has provided assistance in the form of financial assistance, this certainly has not fulfilled all the needs in the implementation of the one village one early childhood education program [6]. Therefore, the government also involves the participation of women (Bunda PAUD) in community development efforts in order to encourage people to participate in the implementation of early childhood education where they work [8]. Bunda PAUD also plays a role in finding funding and resource solutions to support the delivery of early childhood education services.

Bunda PAUD is the wife of a regional head of a region. Bunda PAUD is determined based on a decree starting from the Central, Provincial, Regency or City, District and Village levels [9]. By including Bunda PAUD as the activator to organize early childhood education programs, this program becomes a program that involves women's support. In addition, the socialization of care programs has more impact when women have a role in managing it, this is because it has become a culture in society for women to be involved in caring because of a woman's authority [10].

The discourse related to the early childhood education program, which was carried out in Indonesia, has economic and political ties. With early childhood education, human resources who meet criteria such as teachers and policy makers are needed [11]. The authorities in implementing the early childhood education program in Indonesia are those who have a role in exercising power [12]. In addition, teachers in early childhood education were women who had a strong instinct for parenting, so they volunteered to become teachers without being able to reject the existing regulations [13].

The existence of early childhood education in Indonesia cannot be separated from the role of the national economy. As already mentioned, the one village one early childhood education program is a pilot program in which village funds can be used for early childhood education infrastructure development [8]. In addition, for the implementation of programs related to education, a $20 \%$ allocation of funds from the National Budget (APBN) is allocated [14]. In other words, the discourse on early childhood education in villages is an impulse from political, economic and national policy factors [11].

\section{EARLY CHILDHOOD EDUCATION (ECE) PRACTICE IN INDONESIA}

In accordance with the Dakar Declaration in 2000 which was held in Senegal [15] regarding Education for All, the Indonesian government, especially in the field of education, issued an appeal regarding One Village One ECE. With this appeal, various types of early childhood education have started to appear according to the needs and abilities of the community. Education for children before the basic education level has been carried out since the enactment of Law Number 20 of 2003 concerning the National Education System [16] in the form of kindergarten. Over time, a form of education for children started to develop, which was intended from the age of 0 to 6 years [17].

Based on Law Number 20 of 2003 concerning the National Education System, early childhood education is an effort to stimulate children from birth to six years of age with the aim of preparing children for the next level of education. With the existence of this regulation and the appeal related to One Village One ECE, there are types of early childhood education intended for children according to the age and stimulation needed by the child [18]. It does not only apply to urban communities or middle and upper economic communities, early childhood education is also intended for children in rural 
areas with the majority of the middle to lower class society.

The administration of early childhood education in Indonesia is divided into three tracks: formal, nonformal, and informal early childhood education. The forms of formal early childhood education are such as Kindergarten and Raudhatul Atfal (RA). Kindergarten and RA are intended for children aged 4-6 years old with the priority for children of 5 years old [19]. For the implementation system, Kindergarten and RA are led by a school principal who is selected by the local government or by the education foundation which manages the Kindergarten or RA institution. For example, non-formal children are Playgroups and Child Care. Playground is an early childhood education with the majority of children aged 2-6 years, where the main priority for students is 3-4 years old [20]. Meanwhile, Child Care is intended for children who need guidance by applying the Three A principles or commonly known as Asah, Asih, Asuh [21]. The majority of Child Care students are children with working parents, so the duration of study at Child Care varies according to community needs. In accordance with the technical guidelines for implementation, Child Care can be located anywhere, such as in residential areas, offices, and even malls. Playground and Child Care are led by a manager who is determined by the Education Foundation of the institution. For now, Playground and Child Care are private or belong to educational foundations because Playground and Child Care are non-formal early childhood education institutions.

For informal early childhood education, one example is Pos Paud, which includes similar other forms of ECE (SPS), Posyandu, and development of families with children under five. The Pos Paud was established with the aim of facilitating children from birth up to 6 years of age in order to get early childhood education services even though the existence of formal and non-formal early childhood education is difficult to reach. The Pos Paud itself was established by village cadres or volunteers who became instructors or implementers of teaching and learning activities. As for the implementation mechanism, Pos Paud is established by policy makers at the village level, so the ownership of Pos Paud is not private, but belongs to the village [22].

Although in the technical guidelines for the implementation of ECE institutions there are different standards that reflect the characteristics of each institution, basically the assessment of the quality of education is contained in the same instrument. In the Regulation of the Minister of Education and Culture Number 13 of 2018 concerning the National Accreditation Board for Schools / Madrasahs and the National Accreditation Board for Early Childhood Education and Non-Formal Education, it is stated that accreditation is carried out to assess the quality of educational institutions. Assessment carried out through accreditation is based on an assessment instrument consisting of eight standards [23] which have been determined in the National Education System Law in order to determine the feasibility level of each institution [24]. With the existence of equality of services, the assessment instruments for quality and age susceptibility of students are relatively the same, it should not be necessary to separate the implementation track. The division of the implementation route will only give new problems in the form of superior program competition [25] which will eventually end up fighting over students.

The division of administration tracks (which consist of formal, non-formal, and informal) rather emphasizes the influence of power in the education sector. Power contributes to the development of education policy [13]. By dividing the educational track, it means involving many policy makers in regulating and determining the rulers of policy [26]. As is well known, RA and Kindergarten are early childhood education units that are on the formal track, but Kindergarten is under the policies of the Ministry of Education and Culture, both from administrative and implementation aspects such as curriculum. Meanwhile, RA, although on the formal track, but the highest authority holder is under the auspices of the Ministry of Religious Affairs; Thus, from the existing curriculum point of view, RA was heavily guided by the decision of the Ministry of Religious Affairs. This proves that policy decisions are still related to the ongoing bureaucracy and politics [11].

Other than correlated with the bureaucracy and politics, the division of tracks in ECE also impacts the driving organizations, such as the Indonesian Association of Kindergarten Teachers (IGTKI), Indonesian PAUD Association (Himpaudi), and Association of Raudhatul Atfal Teachers (IGRA). Each of these driving organizations has its own political interest. IGTKI moves in formal education and Himpaudi moves in non-formal education. Therefore, in the implementation of the socialization mechanism, these driving organizations only promote their own programs [27]. Besides, the differences between these organizations also influence the decisions that will be made by the policy makers [13]

The impulses from various factors such as the policy, other parties' involvement such as driving organization and women groups, and the stakeholders' decision have made ECE in Indonesia to have many differences in its type of institution. The organizations that support the implementation of early childhood education have become the "extended hands" of the government in promoting information regarding the policies [28], thus affecting the practice within the society [29]. As a result, the involvement of other factors such as the politics, economy, and the supporting groups are able to influence the stakeholders and policymakers in regulating the policy on early childhood education. 


\section{CONCLUSION}

Based on the explanation above, it can be concluded that early childhood education in Indonesia is a part of the government's political and economic program. Political and economic involvement encourages the formation of policies that apply in society [29]. Impulses from certain organizations and groups, such as the women group, encouraged the policy makers to regulate the existence of early childhood education in Indonesia, thus providing different understandings in the society according to the model of the educational institution. Furthermore, the involvement of driving organizations also influences the policy.

\section{AUTHORS' CONTRIBUTIONS}

The authors contributed in determining the ideas in this article. The first author is responsible to observe policies regarding ECE and to analyse the policy through critical policy analysis in order to find out the involvement of other factors in a policy regulation. Meanwhile, the second author contributed in the search of data regarding ECE in Indonesia.

\section{ACKNOWLEDGMENTS}

On this occasion, we would like to thank the reviewer team who has provided us with suggestions and advice so this article can meet the quality requirements to become a reference for further research.

\section{REFERENCES}

[1] Direktorat Jenderal Pendidikan Anak Usia Dini dan Pendidikan Masyarakat. Direktorat Pembinaan Paud [Internet]. Direktorat Jenderal Pendidikan Anak Usia Dini dan Pendidikan Masyarakat. 2020 [cited 2020 Nov 11]. Available from: https://pauddikmas.kemdikbud.go.id/DitjenPAUDDikmas/topic 155 .

[2] Manajemen Paud dan Dikmas. Jumlah Satuan Pendidikan PAUD [Internet]. Manajemen Paud dan Dikmas. 2020 [cited 2020 Nov 11]. Available from: https://manajemen.paud-dikmas.kemdikbud .go.id/Rekap/PAUD-Satuan-Pendidikan.

[3] Anggun Paud. Komitmen Indonesia Hebat Lewat PAUD HI [Internet]. Anggun Paud- Ruang Guru dalam Jaringan. 2018 [cited 2020 Nov 8]. Available from: https://anggunpaud.kemdikbud.go. id/index.php/berita/index/20180926083939/Komit men-Indonesia-Hebat-Lewat-PAUD-HI.

[4] Republik Indonesia. Undang-Undang Republik Indonesia tentang Sistem Pendidikan Nasional. 20 Indonesia; 2003.

[5] Mushlih A, Rahimah, Insiyah M, Muzdalifah, Uminar AN, Imami F, et al. Analisis Kebijakan
PAUD: Mengungkap isu-isu menarik seputar AUD. Mangku Bumi. Wonosobo: Mangku Bumi; 2018.

[6] Tsani I. Program 1 Desa 1 Paud [Internet]. Anggun Paud- Ruang Guru Paud. 2018 [cited 2020 Nov 11]. Available from: https://anggunpaud.kemdikbud. go.id/index.php/berita/index/20181122110006/Prog ram-1-Desa-1-PAUD.

[7] Nugraheni S, Fakhruddin. Persepsi dan partisipasi orang tua terhadap lembaga Paud sebagai tempat pendidikan untuk anak usia dini (Studi pada orang tua di Desa Tragung Kecamatan Kandeman Kabupaten Batang). J Non Form Educ Community Empower [Internet]. 2014;3(2):49-57. Available from: https://journal.unnes.ac. id/sju/index.php/jnfc/ article/view/3739/3353.

[8] Adriany V, Yulindrasari H, Tesar M. Satu Desa , Satu Paud - One Village, One Centre Unpacking the meaning of children' $s$ participation within ECE policy and provision in Indonesia. In: The Routledge International Handbook of Young Children's Rights [Internet]. 1st ed. London: Routledge; 2019; 66-76. Available from: https://doi.org/10.4324/978036 7142025 .

[9] Maulipaksi D. Bunda Paud Berperan Penting Wujudkan Paud Berkualitas di Daerah [Internet]. Kementerian Pendidikan dan kebudayaan. 2019 [cited 2020 Nov 11]. Available from: https://www.kemdikbud.go.id/main/blog/2019/11/b unda-paud-berperan-penting-wujudkan-paudberkualitas-di-daerah.

[10] Ball DL. Reflections and deflections of policy: The Case of Carol Turner. Educ Eval Policy Anal [Internet]. 1990;12(3):247-59. Available from: https://doi.org/10.3102/01623737012003247.

[11]Rogers R. An Introduction to Critical Discourse Analysis in Education. Lawrence Erlbaum Associates. New Jersey, London: Lawrence Erlbaum Associates, Inc; 2004.

[12]Edmondson J. America Reads: A critical policy analysis. International Reading Association Newark, DE: International Reading Association; 2000.

[13] Woodside H, Jiron. Language, power, and participation: Using critical discourse analysis to make sense of public policy. In: An Introduction to Critical Discourse Analysis in Education. New Jersey, London: Lawrence Erlbaum Associates, Inc; 2004; 173-205.

[14] Republik Indonesia. Undang-Undang Dasar Negara Republik Indonesia Tahun 1945. Indonesia; 1945.

[15] Komisi Nasional Indonesia untuk UNESCO. Education for All (EFA) [Internet]. Komisi Nasional Indonesia untuk UNESCO. [cited 2020 Nov 11]. Available from: https://kniu.kemdikbud. go.id/?page_id=180. 
[16] Masnipal. Siap menjadi guru \& pengelola PAUD profesional. Jakarta: PT Elex Media Komputindo; 2013.

[17] Suyadi, Ulfah M. Konsep dasar PAUD. Bandung: PT Remaja Rosdakarya; 2015.

[18] Sujiono YN. Konsep Dasar Pendidikan Anak Usia Dini. Jakarta: Indeks; 2013.

[19]Direktorat jenderal Paud dan Pendidikan Masyarakat. Petunjuk Teknis Penyelenggaraan Taman Kanak-Kanak [Internet]. 2015 [cited 2020 Nov 11]. Available from: https://drive.google.com/ file/d/1GnzwqHULzOe8rgp7OFuXyp5IswpsDSE/v iew.

[20] Direktorat Jenderal Pendidikan Anak Usia Dini dan Pendidikan Masyarakat. Petunjuk Teknis Penyelenggaraan Kelompok Bermain [Internet]. 2015 [cited 2020 Nov 11]. Available from: https://drive.google.com/file/d/1Oy0bvtnc35AC18P ijG7T9BCho1t2zLB3/view.

[21] Direktorat Jenderal Pendidikan Anak Usia Dini dan Pendidikan Masyarakat. Petunjuk Teknis Penyelenggaraan Taman Penitipan Anak [Internet]. 2015 [cited 2020 Nov 11]. Available from: https://drive.google.com/file/d/1rBIa0m14Eir6rFge HOaFQjhb4aJhOa/view.

[22] Direktorat Jenderal Pendidikan Anak Usia Dini dan Pendidikan Masyarakat. Petunjuk Teknis Penyelenggaraan Pos Paud [Internet]. 2015 [cited 2020 Nov 11]. Available from: https://drive.google.com/file/d/1aqqzHD38kaFWjk LC4dBRUcA56R-4BuNc/view.

[23] Kementerian Pendidikan dan kebudayaan Indonesia. Peraturan menteri pendidikan dan kebudayaan Republik Indonesia tentang badan akreditasi nasional sekolah/madrasah dan badan akreditasi nasional pendidikan anak usia dini dan pendidikan nonformal. 13 Indonesia; 2018.

[24] Direktorat Jenderal Pendidikan Anak Usia Dini dan Pendidikan Masyarakat. Petunjuk teknis pemetaan mutu program dan/atau satuan pendidikan anak usia dini dan pendidikan masyarakat. 01 Indonesia; 2016.

[25] Yulindrasari H. Neoliberal early childhood education policy and women's volunteerism. In: Negotiating Practices of Early Childhood Education. 2014. p.1-12.

[26] Woodside H, Jiron. Critical policy analysis: Researching the roles of cultural models, power, and expertise in reading policy. Read Res Q. 2003;38(4):530-6.

[27]Bernstein B. Pedagogy, Symbolic Control, and Identity: Theory, Research, Critique. Taylor \& Francis. Bristol: Taylor \& Francis; 1996.
[28]MacNaughton G. Doing Foucault in Early Childhood Studies. Routledge. Canada: Taylor \& Francis; 2005.

[29]Foucault M. On the genealogy of ethics: An overview of work in progress. The Foucault Reader. Harmondsworth: Penguin; 1984. 